\title{
Застосування різних методів остеосинтезу та їх ефективність в лікуванні переломів ключиці
}

\author{
YU. O. HRUBAR, V. I. NEVISTIUK, M. YU. HRUBAR \\ SHEI "Ternopil State Medical University by I. Ya. Horbachevsky"
}

\section{APPLICATION OF VARIOUS METHODS OF OSTEOSYNTHESIS AND THEIR EFFECTIVENESS IN THE TREATMENT OF FRACTURES OF THE CLAVICLE}

\begin{abstract}
Автори провели аналіз ефективності застосування різних методів остеосинезу при переломах ключиці. Відзначається тенденція до пошуку більш ефективних методів остеосинтезу при переломах діафізарної частини ключиці. Наближені результати лікування показали, що в 90,62 \% паціснтів, яким остеосинтез проведено LСРпластинами, отримано добрі результати. При застосуванні DСР-пластин такі результати отримано в 83,34 \% травмованих. Остеоситез інтрамедулярним стержнем Богданова дозволив отримати позитивні результати в $72,01 \%$ паціснтів.

The authors analyzed the effectiveness of different methods of osteosynthesis of clavicular fractures. The tendency to seek more efficient methods of osteosynthesis of diaphyseal fractures of the clavicle is marked. Approximate treatment results showed that $90.62 \%$ of patients, who carried LCP osteosynthesis plates, obtained good results. When using DCP plates, these results were obtained in $83.34 \%$ of injured people. Osteosynthesis using Bohdanov rod gives positive results in $72.01 \%$ of patients.
\end{abstract}

Постановка проблеми і аналіз останніх досліджень та публікацій. Переломи ключиці - доволі часте ушкодження опорно-рухового апарата, яке трапляється як у дорослих, так і в дітей. Вони становлять 12,5-26,1 \% всіх переломів у пацієнтів, що перебувають на амбулаторному лікуванні, та $44 \%$ - від переломів кісток плечового пояса $[1,14]$. Найчастіше переломи ключиці трапляються в діафізарній частині $75 \%$, а їх причиною є непряма травма, яка у $84,9 \%$ випадків $є$ наслідком падінь у побуті [2].

Незважаючи на значну кількість ушкоджень ключиці, до сьогодні відсутня єдина тактика у виборі методу лікування. Анатомо-біомеханічні особливості будови ключиці, особливості травмування кістки та параосальних тканин, їх поширеність викликають значні ускладнення як при консервативному, так і при операційному методах лікування.

Після консервативного лікування переломів діафіза ключиці незрощення виникають у 15 \% випадків, а загальна кількість незадовільних результатів становить $31 \%$ [8]. При вивченні віддалених результатів лікування виявлено, що 30-50\% пацієнтів, які перенесли перелом ключиці та лікувалися консервативно, відчували дискомфорт та були незадоволені результатом [12].
Майже неможливо використовувати зовнішню іммобілізацію при множинних переломах ребер, тяжких забоях органів грудної клітки, “флотуючих” переломах плеча $[6,9]$.

S-подібна форма ключиці і іï функціональні особливості викликають нестабільність інтрамедулярного остеосинтезу, що стає причиною ранньої міграції фіксаторів. Дані обставини змушують доповнювати стабілізацію уламків блокуючими елементами або додатково застосовувати зовнішню іммобілізацію $[7,11]$.

Застосування апаратів позавогнищевої фіксації при переломах ключиці викликало ріст ускладнень від 19 до 32,5 \%. Крім того, інтерпозиція м'яких тканин, що часто зустрічається при переломах ключиці, перешкоджає закритій репозиції ііі уламків $[4,5]$.

Застосування накісткових пластин типу АО при діафізарних переломах ключиці в 16,8 \% викликало стандартні ускладнення: сповільнену консолідацію перелому, нестабільність виконаного остеосинтезу, формування несправжніх суглобів $[10,13]$.

В останні роки поліпшення результатів лікування переломів кісток пов'язують із розробкою та впровадженням у практику остеосинтезу блокованих компресуючих пластин (LCP). 
Мета роботи: вивчити застосування різних методів остеосинтезу та їх ефективність при остеосинтезі переломів ключиці.

Матеріали і методи. В основу роботи покладено аналіз результатів лікування 93 хворих із переломами діафізарної частини ключиці, які перебували на стаціонарному лікуванні в клініці з 2006 до 2012 року, і в яких остеосинтез був проведений 3 використанням стержнів Богданова, DCP та LCPпластин. У групі, де проводили дослідження, чоловіків було 72 (77,42 \%), жінок - 21 (22,58 \%). Середній вік чоловіків становив $(34,2 \pm 9,8)$ року, жінок - $(39,7 \pm 6,7)$ року. 3 переломами правої ключиці лікувалося 37 пацієнтів, лівої-56. Аналізуючи частоту випадків переломів ключиці та їх взаємозв'язок 3 віком та статтю, виявлено, що чоловіки найчастіше отримують переломи ключиці у віці 20-29 та 30-39 років. У жінок найбільшу кількість переломів виявлено у віці 40-49 років (рис. 1).

Вивчаючи анамнез травми, встановлено, що при переломах ключиці як у чоловіків, так і жінок домінував непрямий механізм ушкодження (84 (92,30 \%) пацієнти). Лише у 9 (9,70 \%) травмованих достовірною причиною травми був прямий механізм ушкодження.

При непрямому механізмі травми домінували: падіння на витягнуту руку, ділянку плеча на стороні ушкодження або тулуб - $49(52,67 \%)$ випадків. Під час дорожньо-транспортних пригод травмувалися 22 (23,65 \%) пацієнти. У 9 (9,68 \%) хворих причиною переломів ключиці були падіння з велосипеда. Падіння з висоти (будівельні конструкції, дерева, дахи) стало причиною переломів у 8 (8,61\%) потерпілих. Під час занять спортом травмувалися 5 (5,38 \%) пацієнтів. Дорожньо-транспортні пригоди, падіння з висоти, спортивна травма були головною причиною переломів ключиці у чоловіків 55 \%, тоді як у жінок причиною більшості переломів було падіння у побуті на ділянку плеча на стороні ушкодження - 67,6 \%.

Супутні пошкодження були діагностовані в 35 $(37,63 \%)$ пацієнтів. Закрита черепно-мозкова травма (струс головного мозку) була найпоширенішим пошкодженням та виявлена у $19(54,29 \%)$ хворих. Переломи ребер мали місце у $6(17,15 \%)$ травмованих. У 2 з них переломи ребер ускладнилися пневмотораксом, в 1 - гемотораксом, що потребувало дренування грудної порожнини. 3 переломами великих трубчастих кісток на лікуванні перебували $4(11,42 \%)$ пацієнти. Із закритою травмою живота $3(8,57 \%)$ хворих. У 2 із них проведено оперативні втручання на органах черевної порожнини, а в 1 пацієнта виконано лапароцентез. Із “флотуючим" переломом плеча лікували $3(8,57$ \%) пацієнтів.

Остеосинтез стержнем Богданова за Португаловим був виконаний у 43 (46,24 \%) пацієнтів. Остеосинтез DCР-пластинами - у 18 (19,36 \%) травмованих. У 32 (34,40 \%) потерпілих було використано LCP-блоковані пластини. Таким чином, інтрамедулярний остеосинтез застосовано в 43 (46,24 \%) пацієнтів, накістковий - у $50(53,76 \%)$ травмованих. Зміни у використанні металоконструкцій при переломах ключиці наведено на рисунку 2.

Клінічний діагноз усім пацієнтам було встановлено протягом перших 24 год із моменту отримання травми, і він не викликав будь-яких труднощів.

Рентгенографію ділянки перелому проводили в стандартній передньо-задній та аксилярній проекціях. Після клінічного обстеження та передопераційної підготовки пацієнти були прооперовані під загальним знеболенням у положенні на спині з валиком у міжлопатковій ділянці. Дротяний серкляж використовували при остеосинтезі ключиці стержнем Богданова в 22 пацієнтів.

При ризику міграції фіксатора при остеосинтезі ключиці стержнем Богданова застосовували зовнішню іммобілізацію гіпсовою пов'язкою за типом

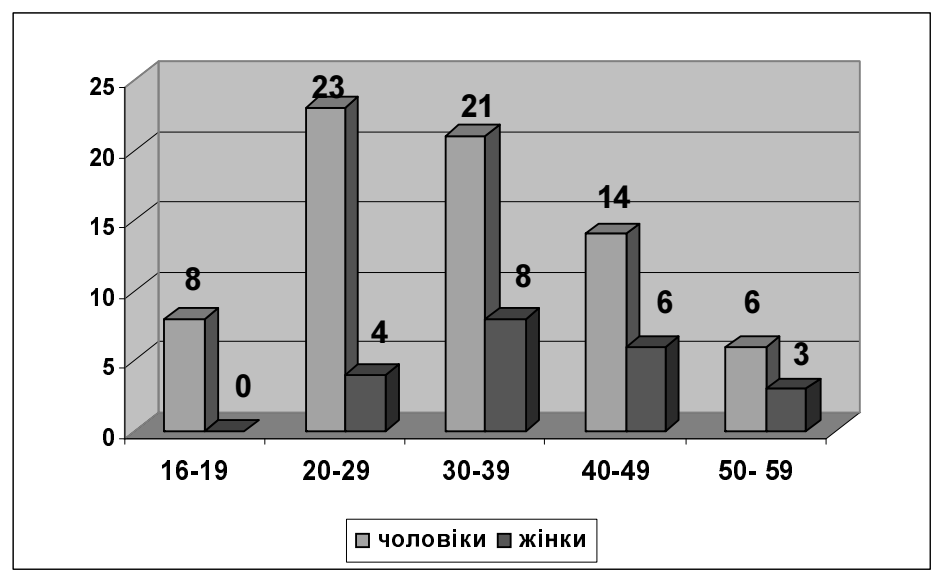

Рис. 1. Частота випадків переломів ключиці та їх взаємозв’язок з віком та статтю. 


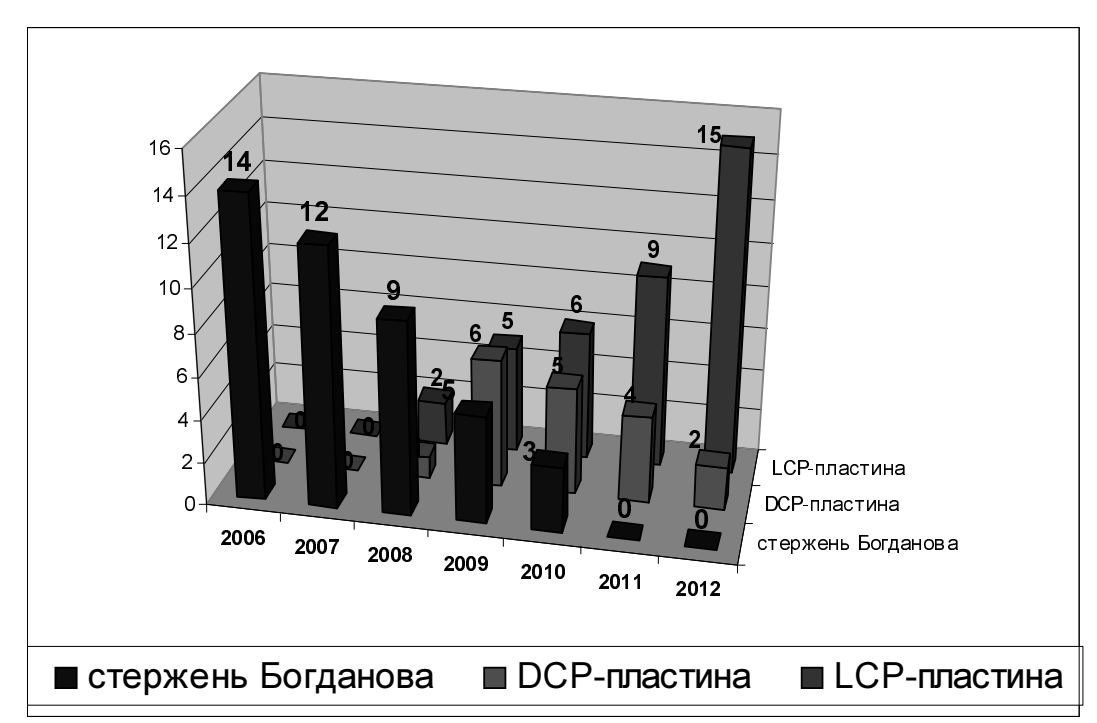

Рис. 2. Динаміка змін у використанні металоконструкцій при переломах ключиці.

Дезо до 4 тижнів. В усіх інших випадках пацієнтам було рекомендовано носити руку на косиночній пов'язці або клиноподібний подушці терміном від 1 до 3 тижнів після операції. Тривалість іммобілізації визначалася больовим синдромом, типом перелому та використаною металоконструкцією. При виписуванні пацієнтів було проінструктовано, щоб вони уникали повторних навантажень упродовж 3 місяців після операційного втручання.

Результати досліджень та їх обговорення. Оцінку результатів ефективності операційного лікування переломів середньої третини ключиці з використанням різних методів остеосинтезу проводили за такими критеріями:

1) якість життя пацієнта:

- відповідає попередньому (3 бали);

- знижена до 50 \% (2 бали);

- знижена більш ніж на 50 \% (1 бал).

2) рентгенологічні дослідження:

- відновлення цілісності кісткової тканини пошкодженого сегмента або зрощення (3 бали);

- частково прослідковується лінія перелому з кістковим мозолем (2 бали);

- нечіткий періостальний мозоль, ознаки сповільненої консолідації перелому (1 бал).

3) функція плечового суглоба:

- повне відновлення функції плечового суглоба (3 бали);

- обмеження флексії, абдукції та ротації в межах $30-60^{\circ}$ (2 бали);

- обмеження флексії, абдукції та ротації в межах 0-30 (1 бал).

Ефективність лікування оцінювали за результатами обстежень пацієнтів у терміни 1,5; 6 та 12 місяців після операції.
Аналізуючи показники якості життя пацієнтів, яким виконано остеосинтез переломів ключиці різними видами фіксаторів, встановлено, що через 1,5 місяця після операційного втручання 15,63\% пацієнтів, яким було виконано остеосинтез LCPпластинами, оцінили свій стан у 3 бали, 78,12\% пацієнтів - у 2 бали та $6,25 \%$ - в 1 бал відповідно до запропонованої бальної шкали. Серед пацієнтів, прооперованих з використанням накісткових DCPпластин, ніхто не зміг оцінити якість життя в 3 бали; в 2 бали оцінили $61,12 \%$ травмованих та в 1 бал $38,88 \%$ травмованих. При застосуванні інтрамедулярних стержнів Богданова 65,12 \% пацієнтів оцінили якість життя в 1 бал та 34,88 \% - у 2 бали.

Через 6 місяців пацієнти, яким виконано остеосинтез LCP-пластинами, оцінили якість життя в 3 бали і становили 65,62\%; у 2 бали - 28,13\%; в 1 бал $-6,25 \%$. У пацієнтів, яким МОС виконано DCPпластинами, отримано такі показники: 3 бали $55,56 \%, 2$ бали - 33,32 \%, 1 бал - 11,12 \% травмованих. У пацієнтів, яким виконано інтрамедулярний остеосинтез стержнем Богданова, одержано такі дані: 3 бали - 27,90 \%, 2 бали - 60,47\% та 1 бал $-11,63 \%$. Через 12 місяців після операційного втручання 81,25 \% пацієнтів, прооперованих з застосуванням LCP-пластин, оцінювали якість життя у 3 бали, в 2 бали $-15,63 \%$ та в 1 бал $-3,12 \%$ травмованих. У пацієнтів, яким металоостеосинтез виконано DCP-пластинами, отримано такі показники: 3 бали - 72,23 \%, 2 бали - 22,22 \%, 1 бал $5,55 \%$ травмованих. Серед пацієнтів, яким виконано інтрамедулярний остеосинтез стержнем Богданова, одержано такі дані: 3 бали - 65,13 \%, 2 бали $-27,90 \%$ та 1 бал $-6,97 \%$ (рис. 3).

Аналізуючи показники консолідації переломів ключиці хворим, яким виконано остеосинтез різними кон- 


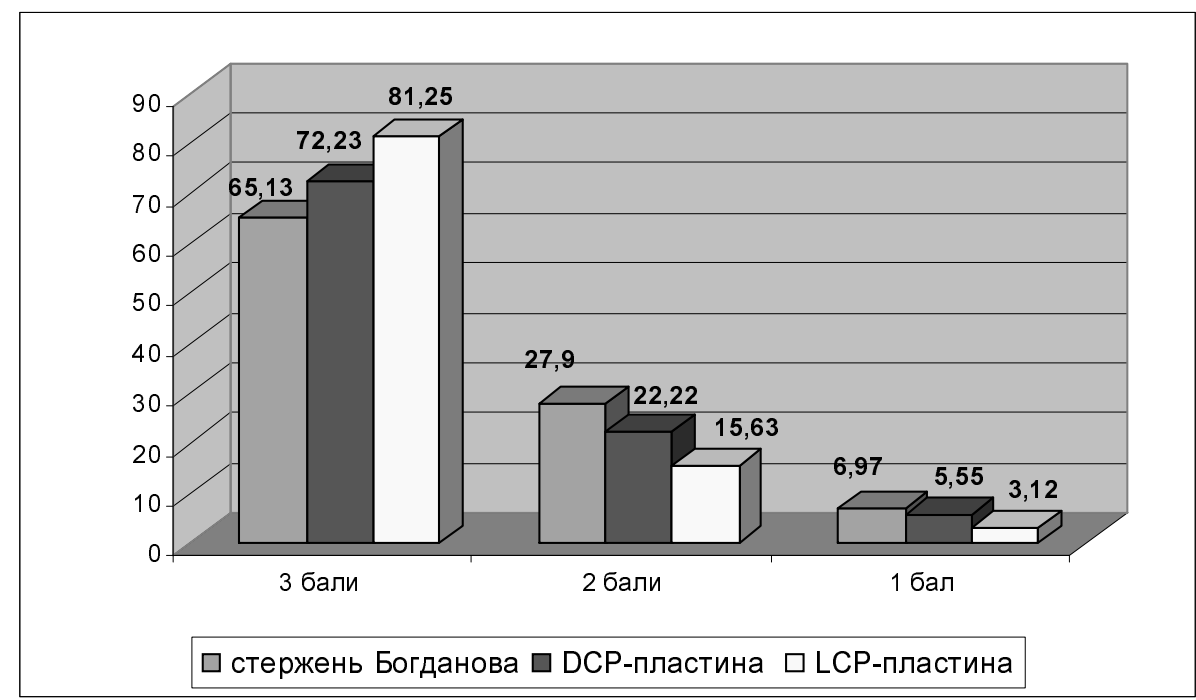

Рис. 3. Показники якості життя пацієнтів, прооперованих різними видами фіксаторів, через 12 місяців після операції.

струкціями, встановлено, що через 1,5 місяця після втручання повної консолідації перелому не виявлено в жодній з груп. У 25,58 \% хворих, яким виконано інтрамедулярний остеосинтез стержнем Богданова, якість кісткової консолідації оцінено в 2 бали. Якість консолідації у травмованих пацієнтів, яким остеосинтез виконано DCP-пластинами, оцінено в 2 бали і становить 44,43 \%, LCP-пластинами - 56,25\%.

Через 6 місяців після втручання отримано такі дані: при остеосинтезі інтрамедулярним стержнем Богданова у 58, 14 \% пацієнтів якість консолідації перелому оцінено в 3 бали, в 2 бали - у 18,60\% та в 1 бал - у 9,30 \%. При застосуванні DCР-пластин: 3 бали - у 61,12 \%, 2 бали - у 27,76 \% та 1 бал - у 11,12\%. При остеосинтезі LCP-пластинами якість консолідації переломів ключиці відповідно до бальної системи оцінки становила: 3 бали - 78,13 \%, 2 бали - 18,75 \%, 1 бал -3,12 \%. Аналізуючи консолідацію перелому в зазначених групах хворих, через 12 місяців встановлено, що при використанні інтрамедулярного стержня Богданова у 72,10 \% пацієнтів настало зрощення перелому, в 1 бал оцінено зрощення перелому в 9,30 \% травмованих. У групі пацієнтів з DCP-пластинами у 83,34 \% досягнуто зрощення перелому (3 бали), в $5,55 \%$ консолідацію оцінено в 2 бали, в 1 бал 11,11 \%. Використання при остеосинтезі LCP-пластин при переломах діафіза ключиці дозволило досягнути повного зрощення у 90,63 \% пацієнтів, у 6,25 \% хворих якість консолідації оцінено в 2 бали. Оцінку в 1 бал отримано в $3,12 \%$ (рис. 4).

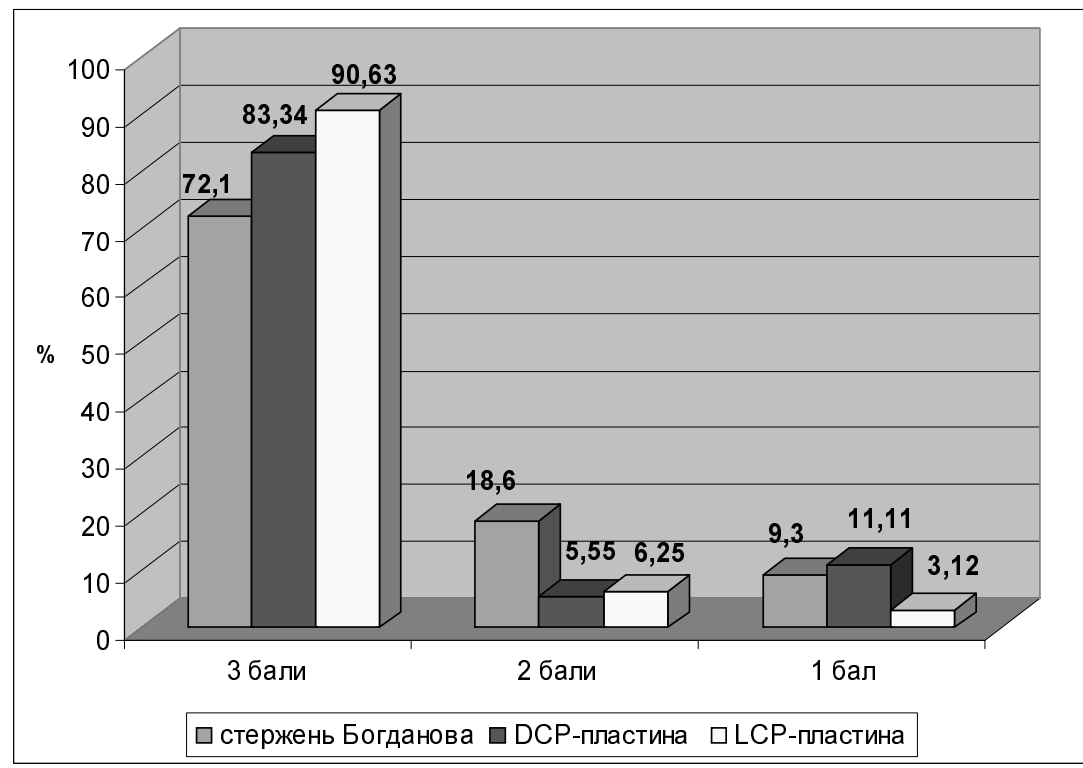

Рис. 4. Показники консолідації переломів ключиці при використанні різних видів фіксаторів через 12 місяців після втручання. 
Усім пацієнтам проводили визначення обсягу рухів у плечовому суглобі на стороні перелому. Завдяки цим даним можна чітко прослідкувати ефективність реабілітаційних заходів, проведених пацієнтам, залежно від методу операційного втручання. 3 отриманих даних випливає, що для подальшої успішної реабілітації найбільш сприятливим методом втручання є остеосинтез LCP-пластинами, бо через 6 місяців $75 \%$ пацієнтів отримали повне відновлення обсягу рухів у плечовому суглобі; в $61,12 \%$ пацієнтів при остеосинтезі DCР-пластинами та в $53,48 \%$ - при остеосинтезі стержнями Богданова. Через 12 місяців після втручання 90,62 \% пацієнтів, яким остеосинтез було проведено LCР-пластинами, відновили повний обсяг рухів у плечовому суглобі, тоді як хворі з DCР-пластинами становили 83,34 \%, а травмовані, яким остеосинтез був виконаний стержнями Богданова, $-72,01 \%$.

Таким чином, добрі результати в операційному лікуванні переломів ключиці при застосуванні LCPпластин отримано в $29(90,62 \%)$ пацієнтів. При використанні в якості фіксаторів DCР-пластин такі результати отримано у 15 (83,34 \%) травмованих. У пацієнтів, яким металоостеосинтез виконувався інтрамедулярним стержнем Богданова, добрі результати отримано в 31 (72,01\%) пацієнта. Причиною незадовільних результатів лікування стали: міграція стержнів, перелом пластини, нестабільність остеосинтезу через раннє навантаження.

\section{СПИСОК ЛІТЕРАТУРИ}

1. Алкалаев С. Б. Методы лечения переломов ключицы / С. Б. Алкалаев, М. В. Фомичёв, В. А. Копысова // Вестник Новосибирского государственного университета. - 2008. Т. 6. - Вып. 2. Ч. 1. - С. 127-137.

2. Остеосинтез ключицы фиксаторами с термомеханической памятью : метод. пособие / [В. А. Копысова, В. А. Каплун, О. В. Непомнящих и др.]. - Новокузнецк : ВНПЦ ИПФ, 2002. $14 \mathrm{c}$.

3. Мацакян А. М. Автореф. на соискание учёной степени канд. мед. наук. - М., 2009. - 17 с.

4. Применение аппарата внешней фиксации в лечении оскольчатого перелома ключицы при сочетанной травме / Э. В. Пешехонов, В. И. Галин, Ю. В. Задулин [и др.] // Военно-мед. журн. - 2005. - Т. 326, № 3. - С. 49-50.

5. Слободской А.Б. Оптимизация лечения пострадавших с переломами и вывихами ключицы методом чрескостного остеосинтеза / А. Б. Слободской // Настоящее и будущее технологичной медицины : тез. докл. Всероссийской науч-практ. конф. Ленинск-Кузнецкий, 2002. - С. 43.

6. Сысенко Ю. М. К вопросу о лечении переломов ключицы / Ю. М. Сысенко, С. И. Новичков // Гений ортопедии. - 2000. № 2. - С. 86-89.

7. Тонких С. А. Причины неудовлетворительных исходов при внутреннем остеосинтезе переломов ключицы / С. А. Тонких,
Висновки. 1. Операційне лікування переломів ключиці залишається до кінця не вирішеною проблемою. Спостерігається тенденція до пошуку більш ефективних методів остеосинтезу при переломах діафізарної частини ключиці, що проявило себе поступовим переходом від остеосинтезу інтрамедулярним стержнем Богданова до DCP- та LCPпластин.

2. Аналізуючи частоту випадків переломів ключиці та їх взаємозв'язок із віком та статтю, виявлено, що чоловіки отримують переломи ключиці в більш молодому віці, ніж жінки. Наближені результати лікування показали, що в 90,62 \% пацієнтів, яким остеосинтез проведено LCP-пластинами, отримано добрі результати. При застосуванні DCPпластин такі результати отримано у 83,34 \% травмованих. Остеосинтез інтрамедулярним стержнем Богданова дозволив отримати позитивні результати у $72,01 \%$.

3. Причиною незадовільних результатів лікування стали міграція стержнів, перелом пластини, нестабільність остеосинтезу через раннє навантаження.

4. Перспективними дослідженнями при остеосинтезі переломів середньої третини ключиці слід вважати вибір оптимального підходу в застосуванні LCP-пластин з урахуванням ступеня зміщення кісткових уламків, виду перелому та обраного типу фіксації.

В. Э. Янковский, А. А. Коломиец // Гений ортопедии. - 2004. № 1. - C. 114-117.

8. Hill J. M. Closed treatment of displaced middle-third fractures of the clavicle gives poor results / J. M. Hill, M. H. McGuire, L. A. Crosby // J. Bone Joint Surg. - 1997. - Vol. 79. - P. 537-539. 9. Kljnz A. Clavicular fractures Unfallchimrg / A. Kljnz, T. Hockertz, H. Reilmann // J. Trauma. - 2001. - Vol. 104, № 1. P. $70-81$.

10. Kljnz A. Clavicular fractures Unfallchimrg / A. Kljnz, T. Hockertz, H. Reilmann // J. Trauma. - 2001. - Vol. 104, № 1. P. $70-81$.

11. Leppilahti J. Migration of Kirschner wires following fixation of the clavicle a report of 2 cases / J. Leppilahti, P. Jalovaara // Acta. Orthop. Scand. - 1999. - Vol. 70(5). - P. 517-519.

12. Nowak J. Clavicular Fractures: Epidemiology, Union, Malunion, Nonunion. Uppsala, Sweden / J. Nowak // Acta Universitatis Upsalaiensis; 2002.

13. Parry D. J. Posttraumatik clavicular pseudoarthrosis an unusual case of venous thoracic outlet syndrome / D. J. Parry, A. Waterworth, D. J. Scott // Eur. J. Vase Endovase Surg. - 2000. - Vol. 20, № 4. - P. 403-404.

14. Epidemiology of clavicle fractures / F. Postacchini, S. Gumina, P. De Santis, F. Albo // J. Shoulder Elbow Surg. - 2002. - Vol. 11. - P. 452-456. 